\title{
Genetic Variability Studies for Yield and Yield Attributing Traits in Brown Sarson (Brassica rapa L.) Genotypes under Temperate Conditions of Kashmir
}

\author{
Tahmeena Bano $^{1}$, Shahina A. Nagoo ${ }^{2 *}$, M. Asif Iqbal Qureshi ${ }^{3}$, M. Altaf Wani ${ }^{1}$, \\ Sanjay Kumar ${ }^{1}$, F. A Sheikh ${ }^{1}$, M. Ashraf Bhat ${ }^{1}$, M. Ashraf Rather ${ }^{1}$, Z. A. Dar ${ }^{4}$,
} Z. I. Buhroo ${ }^{2}$ and Sabiha Ashraf ${ }^{2}$

${ }^{1}$ Faculty of Agriculture-Wadura, ${ }^{2}$ College of Temperate Sericulture-Mirgund, ${ }^{3}$ Saffron Research Station-Pampore, ${ }^{4}$ Dryland Agriculture Research Station-Budgam, Sher-eKashmir University of Agricultural Sciences and Technology of Kashmir Srinagar, $J \& K$, India-190025

*Corresponding author

\section{Keywords}

Brown sarson (Brassica rapa L.), Genetic, Genotypes, Kashmir,

Temperate, Variability, Yield

Article Info

\section{Accepted:}

28 January 2021

Available Online:

10 February 2021
The present study was carried out with 57 genotypes of brown sarson (Brassica rapa L.) during rabi 2019-2020. Estimationof the genetic variability, heritability, genetic advance and correlation analysis in the set of $57 \mathrm{~B}$. rapa lines revealed that all the characters exhibited large amount of variability. The high amount of PCV and GCV along with high values of broad sense of heritability and genetic advance was found, no. of seeds per siliqua, no. of siliqua per plant followed by seed weight. The association analysis showed that the no. of seeds per siliqua, Siliqua length, no. of siliqua per plant and seed weight had significant positive correlation with seed yield plot $^{-1}$. The difference between PCV and GCV were observed low for all the traits. The genetic variability present in the set of breeding material shall not only provide a basis for selection but also provided some valuable information regarding selection of diverse parents to be used in the hybridization programme. Hence, In the present study, significant amount of differences were observed in the studied genotypes for all characteristics which give an insight into the existence of genetic variation in the available genotypes and thus there is a great scope for selection and further improvement of Brassica rapa $\mathrm{L}$ in terms of quality and quantity.

\section{Introduction}

Brassica species have been exploited by man, among all the different oilseed groups, domesticated and modified to meet the altering needs as a source of vegetable oil for centuries. India ranks second area wise and third in production for oilseed brassica crops. Among the rapeseed-mustard group B. juncea is grown on more than 80 per cent of the total 
cultivated area under rapeseed mustard in the country as it suits perfectly in cropping system of rainfed areas. Globally, rapeseedmustard is cultivated over an area of 33.64 mha with production of 72.37 million tonnes (FAO, 2019). During 2018-19, India produced 9.33 million tonnes of Rapeseedmustard from a stretch of 6.23 mha with a productivity of $15.0 \mathrm{q} / \mathrm{ha}$ (Economic Survey, 2020). In the Rapeseed-mustard group, $B$. rapa L. var. brown sarson is cultivated on a larger scale in rabi season in the Kashmir valley. The rapeseed mustard crop occupied an extent of 53000 hectare with the production of 34 thousand quintals and an average productivity of $6.97 \mathrm{q} / \mathrm{ha}$ during 2017-18 in J\&K state (Anonymous, 2018c). The crop suits perfectly in the oilseed-paddy rotation prevalent in the valley and has a great buffering capacity to tolerate the frost conditions. But temperatures below $25^{\circ} \mathrm{F}$ will likely kill stands. The small and round seeds of Brassica contains carbohydrate (14-16 percent), fiber (10-15 percent), moisture (6-8 percent), ash (4-6 percent), mineral (3-4 percent $), \quad$ vitamins $(0.7-0.9$ percent $)$ glucosinolate (2-3 percent), phytic acid (3-6 percent), sinapine (1-1.5percent) and 1.6-3.1 percent of tannin (Agnihotri and Kumar 2004) and about 40 to $44 \%$ oil (dry weight basis) and 38 to $41 \%$ protein, high percentage of oleic acid (60.2 \%), linolenic acid (10.9\%), linoleic acid $(21.3 \%)$, eicosenoic acid $(1.3 \%)$ and low erucic acid $(0.5 \%)$. Much effort has been made to improve methods for recognizing varieties because of its economic value (Cooke 1999). The success of any breeding system, in particular the improvement of specific characteristics through selection, depends entirely on the genetic variation in that crop's germplasm (Yadava et al., 2011). Thus, it becomes necessary for a plant breeder to assess the variability with the assistance of parameters like PCV, GCV, heritability and genetic advance. To achieve higher produce, and thus shift the state's edible oilseed scenario, it is imperative to develop early maturing improved varieties of Brown Sarson with high yielding ability, high oil content, better oil quality. In view of the above fact the study was aimed to evaluate the Brown Sarson (B. rapa L.) genotypes through genetic variability, heritability and genetic advance estimation and correlation analysis.

\section{Materials and Methods}

The experiment was conducted with 57 genotypes of Brown Sarson (Brassica rapa L.) in the experimental farm of the Department of Genetics and Plant Breeding, Sheri-Kashmir University of Agricultural Sciences and Technology, FoA, WaduraKashmir (Table 1). The experiment was laid out in Randomized Complete Block Design (RCBD) with three replications. Ten plants were selected randomly from each plot for collection of data for various yield contributing characters viz. plant height, Plant main Shoot length, siliqua per plant, siliqua length, seeds per siliqua, 1000 seed weight, and yield/plot and average of these ten plants were worked out, however except $50 \%$ days to flowering, maturity and yield data, the data were recorded on whole plot basis. The average values of all of the observations were used for statistical analysis. Genotypic and phenotypic coefficients of variation were calculated according to the formula given by Burton and De-Vane (1953). Heritability was calculated according to the formula given by Hanson et al., (1956). From the heritability estimates the genetic advance was estimated as per Johnson et al., (1955). Correlation coefficients were estimated using the formula given by Miller et al., (1958).

\section{Results and Discussion}

The presence of variability in any crop population is essential for improvement in 
breeding program of a crop (Hasan et al., 2006). The analysis of variance for 11 yield and yield attributing traits of 57 B. rapa L. germplasm genotypes presented in Table-2 depict that the mean total of squares due to genotypes was found to be highly significant in all the traits viz., flowering period, plant height, primary branches per plant, Plant main shoot length, siliqua per plant, seeds per siliqua, length of siliqua, $80 \%$ maturity period, seed weight, oil content and yield per plot. This suggests a significant amount of genetic variation among the genotypes for all the characters under investigation and offers an opportunity for further study and assessment of variability parameters. Rameeh (2014) observed significant differences for the traits including days to flowering, duration of flowering, days to maturity, number of branches, pods main raceme ${ }^{-1}$, pods plant ${ }^{-1}$, seeds pod $^{-1}$, and seed yield and Chaurasiya et al., (2018) recorded highly significant differences for all characters namely, days to $50 \%$ flowering, days to maturity, plant height, number of primary branches plant ${ }^{-1}$, number of secondary branches plant ${ }^{-1}$, number of siliqua plant $^{-1}$, number of seed siliqua ${ }^{-1}, 1000$ - seed weight, biological yield plant $^{-1}$, harvest index, oil content and seed yield plant ${ }^{-1}$.

The coefficient of variation was measured at genotypic and phenotypic rates. Usually, the phenotypic coefficient of variation was greater in magnitude than the coefficient of variation in the genotypes signifying that the variability is not only due to genotypes but also due to the influence of climate. In the current study (Table 3 and 4).

the moderate value of genotypic coefficient of variation (14 to $4 \%$ ) was shown by siliqua number per plant (19.9\%) followed by Primary branches number per plant $(16.8 \%)$, plant length (14.2\%), Plant main shoot length (13.4\%) followed by siliqua length (13.2\%), seed weight (13.0), number of seeds per siliqua (11.0). Moderate magnitude of phenotypic coefficient of variation (PCV) was recorded for number of Siliqua per plant $(21.8 \%)$ followed by number of primary branches per plant (19.8\%), siliqua length (16.66\%), plant main shoot length (16.6\%), number of seeds per siliqua $(16.4 \%)$, plant height (15.8\%), seed weight (14.9\%) Similarly, Rouf et al., (2018) reported moderate PCV and GCV no. of seed per siliqua, 1000 seed weight; Mahendra et al., (2020) in Brassica rapa L. reported moderate GCV and PCV for no of seed per siliqua , plant height. High estimate of heritability broad sense ( $\tilde{\mathrm{A}} 60 \%$ ) was recorded for 50 per cent flowering period $(96.6 \%)$ then for 80 per cent maturity period $(95.1 \%)$, seeds per siliqua (91.6\%), siliqua no. per plant (84.3\%), plant height $(81.5 \%)$ and seed weight $(80.8 \%)$. Maximum broad sense heritability value for the mentioned traits indicates that selection gain to improve this trait would be higher. Similar results of high heritability for $50 \%$ flowering period are in agreement with the observations of Mahendra et al., (2020) in Brassica rapa. Rout et al., (2019) also reported high heritability number of siliqua per plant, Seeds per siliquain Brassica juncea $\mathrm{L}$. The results of high heritability for number of siliqua per plant are in conformity with the findings of MariaIslam et al., 2020 in $B$. rapa. For the traits namely seeds per siliqua (31.2\%), siliqua per plant (30.8\%), thousand seed weight $(27.3 \%)$, siliqua length (20.5\%), the magnitude of genetic advance as a percentage of mean was reported high. High estimates of genetic advance for characters no. of seeds per siliqua and number of siliqua per plant were also stated by Aktaret al., (2019) in Brassica genotypes. All characteristics with high genetic advance values suggest that these traits are regulated by additive genes, and selection will be beneficial for the enhancement of these characteristics. The characters that 
demonstrated strong heritability correlated with strong genetic advance in the present study are no. of seeds per siliqua, no. of siliqua per plant, seed weight. Similar outcomes were described by Rout et al.,
(2019) in B. juncea, Gupta et al., (2019) in B. juncea for siliqua/ plant, seeds/ siliqua and thousand seed weight in $B$. juncea; Lodhi et al., (2014) in B. juncea for no. of seeds per siliqua, seed weight.

Table.1 List of genotypes used in the experiment.

\begin{tabular}{|c|c|c|}
\hline S .No. & Genotype/Germplasm line & Source \\
\hline 01 & KBSG-10 & IPK, Germany \\
\hline 02 & KBSG-92 & IPK, Germany \\
\hline 03 & KBSG-146 & IPK, Germany \\
\hline 04 & KBSG-1 & IPK, Germany \\
\hline 05 & KBSG-45 & IPK, Germany \\
\hline 06 & KBSG-18 & IPK, Germany \\
\hline 07 & KBSG-33 & IPK, Germany \\
\hline 08 & KBSG-2 & IPK, Germany \\
\hline 09 & KBSG-80 & IPK, Germany \\
\hline 10 & KBSG-128 & IPK, Germany \\
\hline 11 & KBSG-8 & IPK, Germany \\
\hline 12 & KBSG-123 & IPK, Germany \\
\hline 13 & KBSG-15 & IPK, Germany \\
\hline 14 & KBSG-147 & IPK, Germany \\
\hline 15 & KBSG-79 & IPK, Germany \\
\hline 16 & KBSG-124 & IPK, Germany \\
\hline 17 & KBSG-19 & IPK, Germany \\
\hline 18 & KBSG-29 & IPK, Germany \\
\hline 19 & KBSG-17 & IPK, Germany \\
\hline 20 & KBSG-74 & IPK , Germany \\
\hline 21 & KBSG-5 & IPK, Germany \\
\hline 22 & KBSG-63 & IPK, Germany \\
\hline 23 & KBSG-68 & IPK, Germany \\
\hline 24 & KBSG-38 & IPK, Germany \\
\hline 25 & KBSG-112 & IPK, Germany \\
\hline
\end{tabular}




\begin{tabular}{|c|c|c|}
\hline 26 & KBSG-39 & IPK, Germany \\
\hline 27 & KBSG-102 & IPK, Germany \\
\hline 28 & KBSG-119 & IPK, Germany \\
\hline 29 & KBSG-141 & IPK, Germany \\
\hline 30 & KBSG-14 & IPK, Germany \\
\hline 31 & KBSG-18 & IPK, Germany \\
\hline 32 & KBSG-140 & IPK, Germany \\
\hline 33 & KBSG-120 & IPK, Germany \\
\hline 34 & KBSG-34 & IPK, Germany \\
\hline 35 & KBSG-151 & IPK, Germany \\
\hline 36 & KBSG-51 & IPK, Germany \\
\hline 37 & KBSG-111 & IPK, Germany \\
\hline 38 & KBSG-66 & IPK, Germany \\
\hline 39 & KBSG-85 & IPK, Germany \\
\hline 40 & KBSG-56 & IPK, Germany \\
\hline 41 & KBSG-64 & IPK, Germany \\
\hline 42 & KBSG-139 & IPK, Germany \\
\hline 43 & KBSG-134 & IPK, Germany \\
\hline 44 & KBSG-130 & IPK, Germany \\
\hline 45 & KBSG-127 & IPK, Germany \\
\hline 46 & KBSG-122 & IPK, Germany \\
\hline 47 & KBSG-118 & IPK, Germany \\
\hline 48 & KBSG-116 & IPK, Germany \\
\hline 49 & KBSG-114 & IPK, Germany \\
\hline 50 & KBSG-110 & IPK, Germany \\
\hline 51 & KBSG-107 & IPK, Germany \\
\hline 52 & KBSG-105 & IPK, Germany \\
\hline 53 & KBSG-103 & IPK, Germany \\
\hline 54 & KBSG-109 & IPK, Germany \\
\hline 55 & SS-1 (Check) & SKUAST-K \\
\hline 56 & SS-2 (Check) & SKUAST-K \\
\hline 57 & SS-3 (Check) & SKUAST-K \\
\hline
\end{tabular}


Table.2 Analysis of variances for yield and yield attributing traits in Brassica rapa L. genotypes

\begin{tabular}{|c|c|c|c|c|c|c|c|c|c|c|c|c|}
\hline Source & $\begin{array}{l}\text { Degree } \\
\text { of } \\
\text { freedom }\end{array}$ & $\begin{array}{c}\text { PMSL } \\
\text { (cm) }\end{array}$ & PH (cm) & NPBPP & NSPP & $\mathrm{SL}(\mathrm{cm})$ & NSS & $\begin{array}{l}\text { SW } \\
(\mathrm{g})\end{array}$ & $\begin{array}{c}\text { Df } \\
\text { (day) }\end{array}$ & $\begin{array}{c}\text { DM } \\
\text { (day) }\end{array}$ & $\begin{array}{l}\text { Seed } \\
\text { yield } \\
\text { plot }^{-1}\end{array}$ & $\begin{array}{c}\text { Oil } \\
\text { content } \\
(\%)\end{array}$ \\
\hline Replication & 2 & 465.71 & 0.24 & 3.23 & 0.08 & 3.69 & 4.21 & 1.58 & 1.61 & 2.74 & 0.05 & 0.01 \\
\hline Treatment & 56 & $1101.64^{*}$ & $1561.42^{*}$ & $2710.26^{*}$ & $12815.38^{*}$ & $23.61^{*}$ & $229.91^{*}$ & $0.65^{*}$ & $58.18^{*}$ & $179.0^{*}$ & $4.43^{*}$ & $18.20^{*}$ \\
\hline Error & 112 & 244.84 & 18.93 & 0.54 & 0.37 & 0.19 & 0.70 & 0.11 & 0.96 & 0.87 & 0.21 & 0.30 \\
\hline
\end{tabular}

*Significant at 0.05 level of significance

$\mathrm{PMSL}=$ Plant main shoot length, $\mathrm{PH}=$ Plant height, $\mathrm{NPBPP}=$ Number of primary branches plant ${ }^{-1}, \mathrm{NSPP}=\mathrm{Number}$ of siliqua $\mathrm{plant}{ }^{-1}, \mathrm{SL}=\mathrm{Siliqua}$ length, $\mathrm{NSS}=$ Number of seeds siliqua ${ }^{-1}, \mathrm{SW}=1000$ seed weight, $\mathrm{DF}=$ Days to $50 \%$ flowering, DM=Days to 80\% maturity, seed yield Plot ${ }^{-1}(\mathrm{~kg})$, Oil content $(\%)$. 
Table.3 Estimation of genetic parameters for yield and yield attributing traits in Brassica rapa L. genotypes

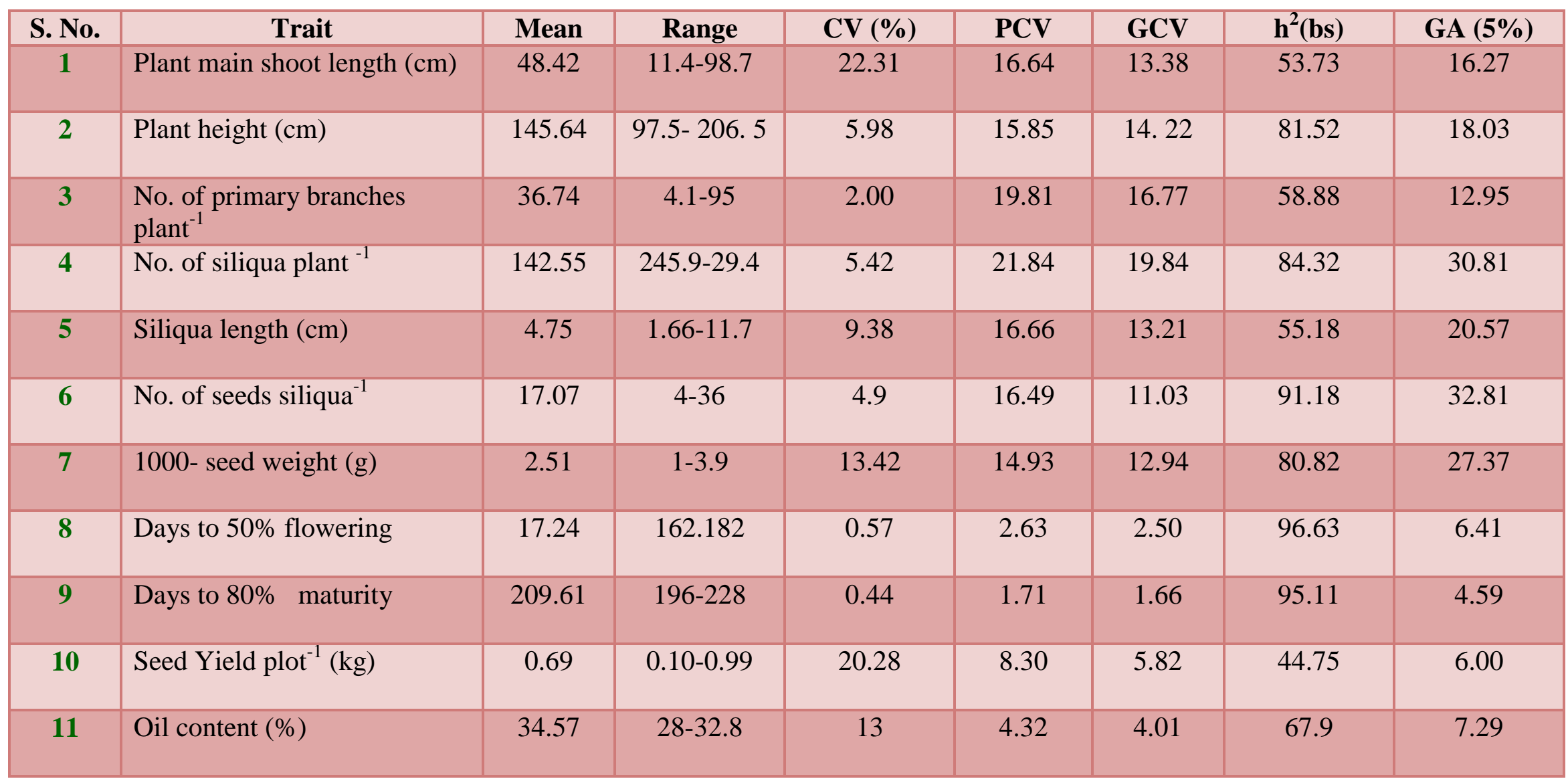

$\mathrm{DF}=$ days to $50 \%$ flowering, $\mathrm{PH}=$ plant height $(\mathrm{cm}), \mathrm{NPBPP}=$ Number of primary branches per plant, $\mathrm{PMSL}=\mathrm{Plant}$ main Shoot length $(\mathrm{cm})$, NSPP= number of siliqua per plant, NSPS= number of seeds per siliqua, $\mathrm{S} . \mathrm{L}=$ siliqua length $(\mathrm{cm}), \mathrm{DM}=$ days to $80 \%$ maturity, $\mathrm{SW}=$ seed weight $(\mathrm{g}), \mathrm{OC}=$ oil content $(\%), \mathrm{YP}=$ yield per plot $(\mathrm{kg})$. 
Table.4 Correlation analysis of yield and various yield attributing traits in Brassica rapa genotypes.

\begin{tabular}{|c|c|c|c|c|c|c|c|c|c|c|c|}
\hline & PMSL & PH & NPBPP & NSPP & SL & NSS & 1000SW & DF & DM & Yield & $\operatorname{Oc}(\%)$ \\
\hline PMSL & - & 0.94 & $0.76^{* *}$ & 0.90 & 0.86 & 0.91 & 0.41 & $0.033^{*}$ & 0.036 & 0.55 & $0.034^{*}$ \\
\hline PH & & - & $0.684^{* * *}$ & 0.878 & 0.792 & 0.874 & 0.497 & $0.079^{*}$ & 0.068 & 0.525 & -0.039 \\
\hline NPBPP & & & - & 0.901 & 0.953 & 0.918 & 0.607 & $0.025^{* *}$ & $0.192^{* *}$ & 0.827 & 0.431 \\
\hline NSPP & & & & - & 0.919 & 0.962 & 0.617 & $0.064^{* *}$ & $0.120^{* *}$ & $0.214^{* *}$ & 0.733 \\
\hline SL & & & & & - & 0.966 & 0.594 & $0.072^{*}$ & $0.180^{* *}$ & $0.748^{* *}$ & 0.295 \\
\hline NSS & & & & & & - & 0.586 & $0.074^{* *}$ & $0.154^{* *}$ & $0.744^{* *}$ & 0.224 \\
\hline SW & & & & & & & - & 0.337 & 0.327 & $0.584^{* * *}$ & 0.291 \\
\hline DF & & & & & & & & - & 0.832 & $0.124^{*}$ & -0.047 \\
\hline DM & & & & & & & & & - & 0.301 & 0.175 \\
\hline Yield & & & & & & & & & & - & 0.509 \\
\hline
\end{tabular}


Association studies between yield and yield contributing characters

The yield coefficients for correlation and various character attributes are given in Table 3 . The yield per plot $(\mathrm{kg})$ displayed positive and highly significant association with number of siliqua plant ${ }^{-1}(0.21)$, siliqua length (0.748), number of seeds siliqua ${ }^{-1}(0.74), 1000$ seed weight (0.58). Oil content showed negative and significant association with days to flowering (-0.04) and plant height (0.03). Days to 80 per cent maturity showed positive and highly significant association with days to number of primary branches per plant, number of siliqua per plant, siliqua length, and number of seeds per siliqua. Similarly, plant main shoot length displayed positive and highly significant association with no. of primary branches per plant (0.76) and Oil content (0.034). The plant length exhibited positive highly significant association with no. of primary branch per plant (0.68), while as, seed no. per siliqua presented positive and highly significant association with days to 50 $\%$ flowering (0.74), and days to $80 \%$ maturity (0.15). The siliqua no. per plant exhibited positive and highly significant association with days to $50 \%$ flowering (0.064) and days to $80 \%$ maturity (0.12). Siliqua length exhibited positive and significant association with days to $50 \%$ flowering (0.072)and days to $80 \%$ maturity $(0.18)$.The results revealed by Tabassum et al., (2021) in Brassica rapa L., and Mudha Aggarwal et al., (2019) in Brassica juncea L. stated positive correlation between no. of primary branches per plant and yield in their study. Maria Islam et al., (2020) and Nitesh kumar et al., (2019) in Brassica rapa L., reported a significant and positive genotypic correlation of number of siliqua per plant, with yield. Positive association between desirable characteristics is beneficial as it allows all characters to develop simultaneously. Negative correlation, by contrast, would impede the simultaneous expression of both high value characters. In such a case there has to be some economic compromise.

In conclusion, study with 57 genotypes of brown sarson ( Brassica rapa L.) revealed significant amount of differences among the genotypes for all characteristics which gives an insight into the existence of genetic variation in the available genotypes reflecting that there is a great scope for selection. Traits like, no. of seeds per siliqua, Siliqua length, seed weight, and no. of siliqua per plant have high heritability as well as high genetic advance and selection can be based on these traits. Correlation analysis furnishes a basis in determining the relative contribution of each character to seed yield. Trait Number of seeds per siliqua, siliqua length, no of seeds per siliqua and seed weight displayed positive and highly significant association with yield per plot. Therefore, selection of these characters would be more effective for the improvement of the crop.

\section{Acknowledgement}

With due thanks, I hereby acknowledge the support from Head Division of Genetics and Plant Breeding, Faculty of AgricultureWadura, Sher-e-Kashmir University of Agricultural Sciences and Technology of Kashmir Srinagar for providing me with the facilities in pursuit of this research program.

Competing Interest: the authors declare no conflict of interest in the publication of this manuscript.

\section{References}

Aktar T, Nuruzzaman M, Rana MS, Huda MM, Hossain MA and Hassan L. 2019. Genetic parameters and diversity studies of yield and yield contributing characters in Brassica genotypes. J Bangladesh Agric Univ 17: 295-300. 
Aggarwal M, Punia M.S and Monika 2019. Correlation and Heterosis Studies in various Populations of Indian Mustard (Brassica juncea L. Czern\&Coss). International Journal of Current Microbiology and Applied Sciences ISSN: 2319-7706 Volume 8 Number 03 (2019) .

Agnihotri, A. and Kumar, S. 2004. Quality enhancement and value addition in rapeseed-mustard. In: Kumar A and Singh NB. (eds). Rapeseed-Mustard Research in India. NRCRM, Bharatpur, pp212-230.

Anonymous. 2018. Digest of Statistics, Directorate of Economics and Statistics, Planning and Development Department, J\&K. 107-112

Cooke RJ. 1999. Modern methods for the cultivar identification and the transgenic plant challenge. Seed Sci Technol 27: 669-680.

Gupta M, Roy HS and Bhadauria SS. 2019. Genetic variability analysis in F2/F3 population derived through inter-specific hybridization in oilseed Brassica. Electronic J Plant Breed 10: 1275 - 1282.

Hasan MF, Seyis AG, Badani J, PonsKuhnemann W, Friedt W and Snowdon RJ. 2006. Analysis of genetic diversity in the B. napus L. gene pool using SSR markers. Genetic Resour Crop Evol 53: 793-802.

Islam M.Bhuiyan R.S. Md, Karim R.Md, Rahman S.Md, Habib A. Md, Morshed M. 2020 Variability and path- coefficient in advanced lines of rapeseed (Brassica rapa L.). Life Science Informatics Publications 10.26479/2020.0604.08.

Kumar N, Sarkar S and Bhattacharyya PK.
2019. Association studies for yield components in mustard (B. junceaand $B$. rapa) in Gangetic alluvium zone of West Bengal. Journal of Pharmacog Phytochem 8: 3057-3063.

Lodhi B, Thakral NK, Avtar R and Singh A. 2014. Genetic variability, association and path analysis in Indian mustard (B. juncea). J Oilseed Brassica 5: 26-31.

Mahendra, Salam, J.L, Sonali Kar, Saxena R.R, Bhanwar R.R, T. Chandrakar T, Singh R and Rohit 2020 Genetic Diversity Estimation in Toria [Brassica rapa (L)] Genotypes Collected from Bastar Plateau. Int.J.Curr.Microbiol. App.Sci., 9(3): 2577-2584.

Rauf MA and Rahim MA. 2018. Genetic variability studies among yield and its contributing traits in mustard (B. napus L.). Adv Zool Bot 6: 101-108. 4: 330340.

Rout S, Kerkhi SA and Gupta A. 2019. Estimation of genetic variability, heritability and genetic advance in relation to seed yield and its attributing traits in Indian mustard. J Pharmacog Phytochem 8: 4119-4123.

Tabassum, Jeena A.S., Negi S.A and Koujalagi D. 20 20Correlation and path coefficient analysis on different yield components in germplasm accessions collected from Uttarakhand hills. Green Farming Vol. (2 \& 3) 135-138.

Yadava DK, Giri SC, Vignesh M, Vasudev S, Yadav AK, Dass B, Singh R, Singh N, Mahapatra T and Prabhu KV. 2011. Genetic variability and trait association studies in Indian mustard (B. juncea L.) Indian J Agric Sci 81: 712-716.

\section{How to cite this article:}

Tahmeena Bano, Shahina A. Nagoo, M. Asif Iqbal Qureshi, M. Altaf Wani, Sanjay Kumar, F. A Sheikh, M. Ashraf Bhat, M. Ashraf Rather, Z. A. Dar, Z. I. Buhroo and Sabiha Ashraf. 2021. Genetic Variability Studies for Yield and Yield Attributing Traits in Brown Sarson (Brassica rapa L.) Genotypes under Temperate Conditions of Kashmir. Int.J.Curr.Microbiol.App.Sci. 10(02): 3535-3544. doi: https://doi.org/10.20546/ijcmas.2021.1002.389 